\title{
Photoinhibition of FeFe hydrogenase
}

Matteo Sensi, ${ }^{\dagger, \nabla}$ Carole Baffert, ${ }^{\dagger}$ Laura Fradale, ${ }^{\dagger}$ Charles Gauquelin, " Philippe Soucaille, Isabelle Meynial-Salles, ${ }^{\prime}$ Hervé Bottin, ${ }^{\perp}$ Luca de Gioia, ${ }^{\nabla}$ Maurizio Bruschi, ${ }^{\nabla}$ Vincent

Fourmond ${ }^{\dagger}{ }^{C}$ Christophe Léger ${ }^{*},{ }^{\dagger}$ and Luca Bertini ${ }^{*, \nabla}$

† Aix Marseille Univ., CNRS, BIP UMR 7281, Marseille, France

‡ Department of Earth and Environmental Sciences, Milano-Bicocca University, Piazza della Scienza 1, 20126 Milan, Italy

// Université de Toulouse, INSA, UPS, INP, LISBP, INRA:UMR792,135 CNRS:UMR 5504, avenue de Rangueil, 31077 Toulouse, France

$\perp$ Institut de Biologie Intégrative de la Cellule (I2BC), Institut Frédéric Joliot, CEA, CNRS, Univ Paris-Sud, Université Paris-Saclay, F-91198, Gif-Sur-Yvette cedex, France.

$\nabla$ Department of Biotechnologies and Biosciences, University of Milano-Bicocca, Piazza della Scienza 2, 20126 Milan, Italy

\section{Abstract}

In the enzyme FeFe hydrogenase, hydrogen oxidation and production occur at the H-cluster, a $\mathrm{Fe}_{6} \mathrm{~S}_{6}$ active site that bears intrinsic carbonyl and cyanide ligands. This enzyme has been coupled to photosensitizers to design $\mathrm{H}_{2}$ photoproduction systems, and yet, according to earlier reports, the enzyme from Desulfovibrio desulfuricans is "easily destroyed" in "normal laboratory light". Here we report direct electrochemistry measurements of the effect of light on the activity of the enzymes from Chlamydomonas reinhardtii and Clostridium acetobutylicum, together with TDDFT and DFT calculations of the reactivity of the excited states of the H-cluster. We conclude that visible light does not inhibit these enzymes, but absorption of UV-B $(280-315 \mathrm{~nm})$ irreversibly damages the H-cluster by triggering the release of an intrinsic $\mathrm{CO}$ ligand; the resulting unsaturated species rearranges and protonates to form a stable, inactive dead-end. Answering the question of which particular hydrogenase can resist which particular wavelengths is important regarding solar $\mathrm{H}_{2}$ production, and our results show that some but not all FeFe hydrogenases can actually be combined with photosensitizers that utilise the solar spectrum, provided a UV screen is used. We suggest that further investigations of the compatibility of hydrogenases or hydrogenase mimics with light-harvesting systems should also consider the possibility of irreversible photoinhibition.

\section{Introduction}

FeFe hydrogenases are enzymes that catalyze the oxidation and evolution of molecular hydrogen at an organometallic active site called the $\mathrm{H}$-cluster (figure 1). The H-cluster consists of a $\mathrm{Fe}_{4} \mathrm{~S}_{4}$ cluster bound by a cysteine to a $2 \mathrm{Fe}$ site. Each of the two iron atoms is coordinated by a carbonyl and a cyanide ligands and the two Fe are bridged by a third carbonyl and an azadithiolate (adt) group. ${ }^{1-4}$ A particular FeFe hydrogenase may house zero (as in the enzyme from Chlamydomonas reinhardtii ${ }^{5}$ ), two (Desulfovibrio desulfuricans ${ }^{6}$ and Megasphaera elsdenii ${ }^{7}$ ) or four (Clostridium pasteurianum ${ }^{8}$ or C. acetobutylicum) accessory FeS clusters involved in electron transfer to/from the redox partner. (See ref ${ }^{9}$ for a recent account on the diversity of FeFe hydrogenases). Spectroscopic investigations have helped to identify various states of the $\mathrm{H}$-cluster, including some of the catalytic intermediates. ${ }^{10}$ It is believed that $\mathrm{H}_{2}$ binds in the catalytic cycle to the state referred to as " $\mathrm{H}_{\mathrm{ox}}$ " (Fe' $\mathrm{Fe}$ ") in which the iron atom that is distal from the $\mathrm{Fe}_{4} \mathrm{~S}_{4}$ cluster $\left(\mathrm{Fe}_{\mathrm{d}}\right)$ has a free coordination site in the apical position. The same binding site is the target of competitive inhibitors such as $\mathrm{CO}$ (refs ${ }^{11,12}$ ) and $\mathrm{O}_{2}$ (refs ${ }^{13-15}$ ). Binding of extrinsic $\mathrm{CO}$ to $\mathrm{H}_{\mathrm{ox}}$ leads to an inactive state termed " $\mathrm{H}_{\mathrm{ox}}-\mathrm{CO} "$ which is also detected after the active site has been destroyed in response to 
oxidative stress, be it oxic $^{16}$ or anoxic: ${ }^{17}$ in the absence of extrinsic $\mathrm{CO}$, the formation of $\mathrm{H}_{\mathrm{ox}}-\mathrm{CO}$ occurs because damage of the $\mathrm{H}$-cluster leads to the release of intrinsic carbonyls, some of which are grabbed by nearby intact $\mathrm{H}$-clusters. The latter reaction has been called cannibalisation. Reductive conditions also inhibit the enzyme, in a complex manner. ${ }^{18,19}$

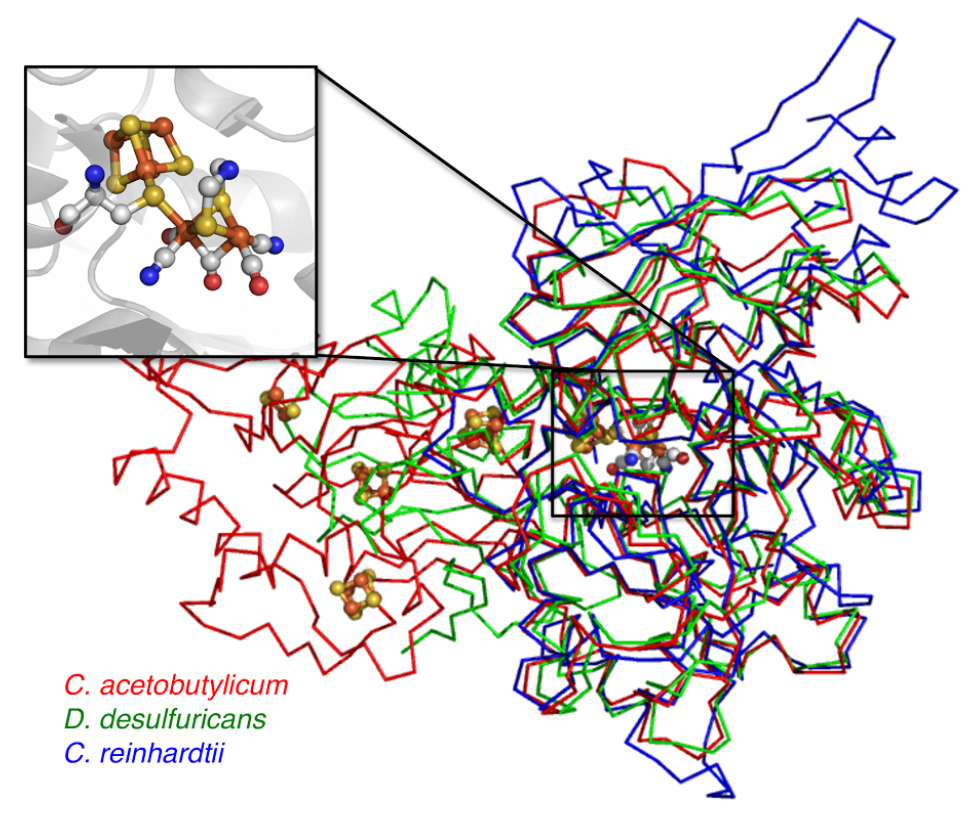

Figure 1. The backbones and active site ("H-cluster") of FeFe hydrogenases discussed in this work (from PDB $3 L X 4,{ }^{5} 1 H F E,{ }^{6}$ and $3 C 8 Y^{8}$ ).

Light affects the H-cluster. The most obvious reason the enzyme is sensitive to UV-vis irradiation is the presence in the active site of photolabile iron carbonyl bonds. That exogenous $\mathrm{CO}$ binds less tightly to the $\mathrm{H}$-cluster under the white light of a halogen lamp than in the dark was discovered more than 40 years ago. ${ }^{20}$ Now we understand the molecular reasons for this: light has no effect on the $\mathrm{CO}$ binding rate, but the absorption of purple or blue light produces an excited state that spontaneously dissociates the exogenous ligand. This results in an increase in the rate of dissociation compared to the kinetics observed in the dark. This effect is small and proportional to the power of the incident light because the $\mathrm{H}$-cluster is a very weak chromophore. ${ }^{21}$ Irradiation in the UVA range $(355 \mathrm{~nm})$ also photo-dissociates exogenous $\mathrm{CO},{ }^{22}$ as was observed in time-resolved infrared spectroscopy experiments designed to monitor the subsequent rebinding of the carbonyl. Illumination with red light $(632.8 \mathrm{~nm})$ results in partial dissociation of exogenous $\mathrm{CO}$ when the enzyme is in the solid state. ${ }^{23}$

Illumination also has other, more complex effects, not all of which could be rationalized at that point. Under certain cryogenic conditions, the photodissociation of $\mathrm{CO}$ from $\mathrm{H}_{\mathrm{ox}}-\mathrm{CO}$ leads to various photoproducts. ${ }^{24}$ With the enzyme in fluid solution $\left(2{ }^{\circ} \mathrm{C}\right.$ to room $\left.\mathrm{T}\right)$, illumination in the presence of exogenous ${ }^{13} \mathrm{CO}$ exchanges the extrinsic and intrinsic $\mathrm{CO}$ ligands. ${ }^{25,26}$ Even more notable, Albracht and coworkers reported in an EPR investigation that the $\mathrm{H}$-cluster of the enzyme from $D$. desulfuricans $(D d)$ is "easily destroyed by light $(\ldots)$ under normal laboratory conditions, i.e. daylight plus the light from fluorescent lamps on the ceiling". ${ }^{27}$ The conversion of the $\mathrm{H}_{\mathrm{ox}}$ form of the $D$. desulfuricans enzyme into the $\mathrm{H}_{\mathrm{ox}}-\mathrm{CO}$ 
state upon illumination with visible light has been detected by FTIR; ${ }^{25,28}$ this was taken as evidence of light-induced $\mathrm{H}$-cluster destruction.

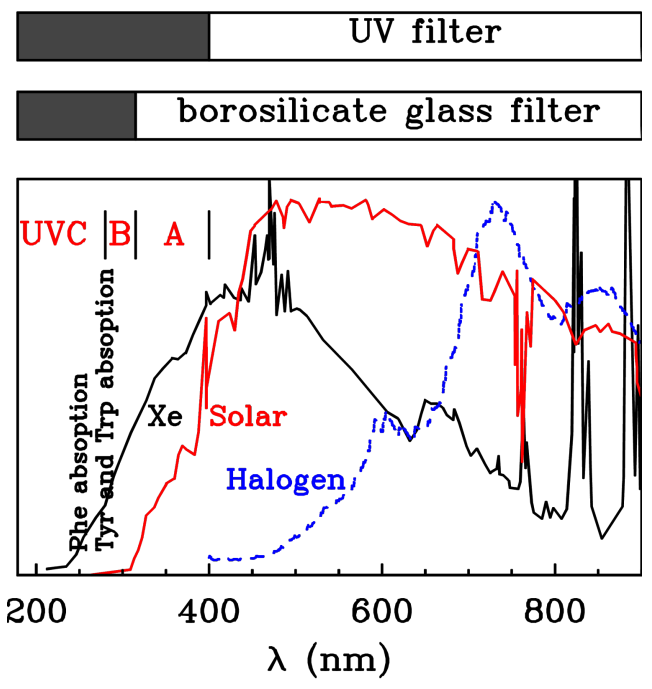

Figure 2. The typical emission spectra of Xe and Halogen lamps (black and dashed blue lines, respectively), and the spectrum of solar irradiation at sea level (red line, from www. newport.com). On top we show the cut-off of the glass and UV filters used in this work (see their absorption spectra in fig. S11). Vertical text indicates the positions of the UV absorption bands of Ph, Tyr and Trp residues. ${ }^{29}$

The conclusion that irradiation destroys the enzyme from $D d$ has not been supported yet by the results of solution assays or by any other experiments with an FeFe hydrogenase from a different organism. Moreover, photoelectrochemical experiments reported so far, where the activity of various FeFe hydrogenases adsorbed onto an electrode is monitored following illumination, ${ }^{30}$ are not consistent with the above-described dramatic effects of visible light. In the experiments of Ruediger et al, the effect of white light on the turnover rate of the enzyme from $D d$ is either mostly reversible (under oxidizing conditions, at $-159 \mathrm{mV}$ vs SHE in $\mathrm{pH} \mathrm{5}$, fig. $2 \mathrm{~A}$ in ref ${ }^{28}$ ) or absent (under reductive conditions, at $-560 \mathrm{mV}$ or $-460 \mathrm{mV}$ vs SHE, $\mathrm{pH} 5$, ibid.). Armstrong et al report no effect of white light on the activity of Chlamydomonas reinhardtii $(\mathrm{Cr})$ and Clostridium acetobutylicum $(\mathrm{Ca})$ hydrogenases, except the photo-induced release of exogenous CO. ${ }^{31}$ In the experiments described in refs ${ }^{28}$ and ${ }^{31}$, all-glass electrochemical cells and halogen lamps were used, suggesting that there was no exposure to UV. In our previous investigation, ${ }^{21}$ we could not detect any irreversible effect of irradiation with monochromatic purple/blue/green or red light on the activity of the FeFe hydrogenases from $\mathrm{Cr}, \mathrm{Ca}$ and Megasphaera elsdenii. This prompted us to examine the effect of UV irradiation, which we report in this work.

Fig. 2 shows the emission spectrum of the so-called white lamps mentioned in earlier studies of hydrogenases and used in this work, together with the solar spectrum that is relevant to the discussion of any device that would aim at using either hydrogenase or hydrogenase mimics and the energy from sunlight to produce hydrogen from water. The obvious difference between tungsten halogen incandescent lamps and Xenon arc lamps is that the latter generate substantial ultraviolet $\mathrm{A}$ and $\mathrm{B}$ radiation. In this work we used a Xe arc lamp, and optional filters that cut the high energy part of the emission (figure S11). We demonstrate that UVB are responsible for irreversible photo-damage to FeFe hydrogenase; we propose a mechanism based on the results of TDDFT calculations of the photoreactivity 
of a small model of the $\mathrm{H}$-cluster, and we use a larger model to run DFT calculations of the structure of the end-product.

\section{Results}

\section{Electrochemical assays}

Fig. $3 A$ and $3 B$ show the change in turnover rates of $\mathrm{H}_{2}$ oxidation and production measured in direct electrochemistry experiments, as we expose the enzymes to light from various sources. ${ }^{30,32}$ The enzyme from $\mathrm{Cr}$ was adsorbed onto a rotating disc electrode poised at $-158 \mathrm{mV}$ or $-508 \mathrm{mV}$ to drive $\mathrm{H}_{2}$ oxidation or production, which is observed as a positive or negative current, respectively. The light beam of a Xe lamp (150 W electrical power according to manufacturer's specifications) was directed by an optical fiber (transmittance range $280-2200 \mathrm{~nm}$ ) towards the surface of the electrode, across a quartz window fused with the bottom of the electrochemical cell (fig. S15).

The signals in panels $A$ and $B$ show that irradiation makes the current decrease faster (the slow background decrease in the dark results from the desorption of the enzyme film). Upon switching on and off the Xe lamp, we saw no instant increase in current which would have resulted from a light induced change in turnover rate (that is, an effect on the catalytic cycle and/or an effect of heating). The effect of irradiation with the Xe lamp is only to slowly transform the active enzyme into a form that cannot oxidize or produce $\mathrm{H}_{2}$. We could measure the time constant of the inactivation from the "light minus dark" difference between the 1 st order rate constants of decay.

This photoinactivation is apparently irreversible: no recovery of activity is observed after the light is turned off. All our attempts to reactivate the enzyme were unsuccessful (we tried to step the potential down or to expose the inactivated enzyme to $150 \mu \mathrm{M}$ exogenous $\mathrm{CO}$, data not shown).

The kinetics of photodamage appears to be independent of the redox state of the H-cluster. Indeed, in our electrochemical experiments, photoinhibition was observed under conditions of oxidative and reductive turnover, although the photoinactivation may be slightly faster when the enzyme is oxidizing $\mathrm{H}_{2}$ than when it is producing $\mathrm{H}_{2}$. Indeed, the decay time constant equates $\tau=24 \pm 5 \mathrm{~min}$ ( $\mathrm{n}=6$ independent determinations) in the range $-258 \mathrm{mV}$ to $0 \mathrm{mV}$, versus $38 \pm 1 \mathrm{~min} \mathrm{n}=2$ at $-508 \mathrm{mV}$, at $30^{\circ} \mathrm{C}, \mathrm{pH} \mathrm{6.8,1}$ bar $\mathrm{H}_{2}$, (Fig. S13); we did not see an effect of varying the electrode potential above the open circuit potential).

Figure $\mathrm{S} 13$ also shows that the kinetics of inactivation of the enzyme from $\mathrm{Cr}$ is the same under 1 and 0.1 bar $\mathrm{H}_{2}$ (the Michaelis constant of FeFe hydrogenase is close to 1 bar, ${ }^{33}$ so the saturation with $\mathrm{H}_{2}$ changes from $50 \%$ to $10 \%$ upon decreasing ten-fold the $\mathrm{H}_{2}$ concentration). 

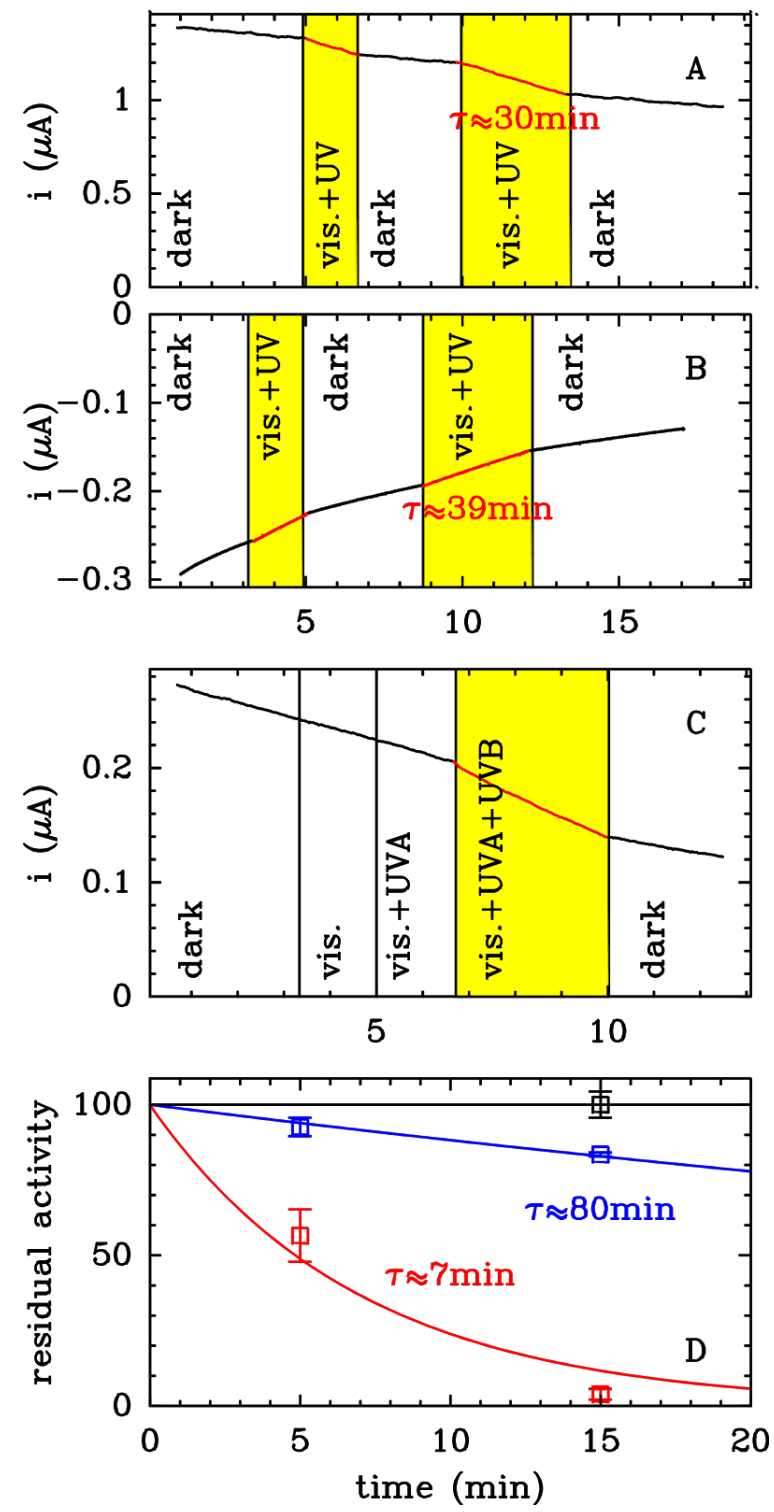

Figure 3. Effect of irradiation on the activity $\left(\mathrm{H}_{2}\right.$ oxidation in panels $A, C$ and $D ; \mathrm{H}_{2}$ production in panel $\mathrm{B}$ ) of Chlamydomonas reinhardtii hydrogenase, measured either electrochemically with the enzyme undergoing direct electron transfer to a rotating electrode (panels $A, B$ and $C$ ), or in a solution assay (panel D). The yellow surfaces indicate simultaneous exposure to visible light, UVA and UVB.

In experiments such as those shown in Panels $A, B$ and $C$, the time constant of inactivation $(\tau)$ was calculated as the reciprocal of the difference between the 1st order rate constants of current decrease measured in the dark and upon irradiation; this corrects from the current decay that is due to film loss. Panel A: hydrogen oxidation at $E=-158 \mathrm{mV} v s \mathrm{SHE}, \mathrm{pH}=6.8$, alternating dark and exposure to the "white light" of a Xe lamp. Panel B: hydrogen production at $E=-508 \mathrm{mV}$ vs SHE (30 ${ }^{\circ} \mathrm{C}, \mathrm{pH}=6.8$ ), alternating dark and exposure to the "white light" of a Xe lamp. Panel C: hydrogen oxidation at $E=-158 \mathrm{mV} v \mathrm{~S} S H E, p H=6.8$, in the dark, upon exposure to the Xe light behind the UV filter, the borosilicate glass filter, or no filter, then in the dark again. Panel $D$ : a stock solution of enzyme ( $p H=8, T R I S / N a C l$ buffer) was kept in a quartz cell at around $T=30^{\circ} \mathrm{C}$, in equilibrium with the atmosphere of the glove box that contained substantial amounts of $\mathrm{H}_{2}$, either in the dark (black point), or subjected to the light of a Xe lamp with (blue data points) or without (red data points) the UV filter, and the $\mathrm{H}_{2}$ oxidation activity was assayed after 5 or 15 minutes (at $30^{\circ} \mathrm{C}, \mathrm{pH} 7$, using $20 \mathrm{mM}$ methyl viologen as electron acceptor). The error bars represent the difference between the results of two independent experiments. 
We repeated the same experiments with the FeFe hydrogenase from $\mathrm{Ca}$ and obtained similar results: the time constant of inactivation upon irradiation with the Xe lamp is $36 \pm 3 \mathrm{~min}$ $\mathrm{n}=5$ in the range $-258 \mathrm{mV}$ to $-58 \mathrm{mV}$, and $34 \pm 4 \mathrm{~min} \mathrm{n}=3$ at $-508 \mathrm{mV}$ (all at $30^{\circ} \mathrm{C}, \mathrm{pH} 6.8$, 1 bar $\mathrm{H}_{2}$, figure $\mathrm{S} 13$ ).

We designed the experiment in fig. $3 \mathrm{C}$ to determine which part of the emission spectrum of the Xe lamp induces the inactivation under oxidative conditions. We used two filters, whose absorption spectra are schematized on top of fig. 2 and plotted in fig. S11: a microscope glass slide and a UV filter, which block the wavelengths shorter than $300 \mathrm{~nm}$ and $340 \mathrm{~nm}$, respectively. The current shown in the inset was recorded (1) first in the dark, (2) then the light was switched on and the two longpass filters interposed between the source and the electrochemical cell, (3) then the UV filter was removed, (4) then the glass filter was also removed, and (5) finally the light was switched off. The observation that either of the two filter prevents photodamage and the fact that the Xe source does not emit in the UVC range (fig. 2), shows that UVB $(280-315 \mathrm{~nm})$ is responsible for inactivating the enzyme. We reached the same conclusion when we repeated the experiments with the enzyme from $\mathrm{Ca}$ (fig. S14).

Similar experiments carried out with $\mathrm{Cr}$ and $\mathrm{Ca}$ hydrogenases under reductive conditions $\left(-508 \mathrm{mV}, \mathrm{pH} 6.8,1\right.$ bar $\left.\mathrm{H}_{2}\right)$ also showed that UV-B is responsible for the photoinhibition (except that both enzymes show a very small sensitivity to UV-A under reductive conditions, fig. S14).

To test whether aromatic residues near the H-cluster may contribute to light absorption, we examined the properties of the F290Y mutant of $\mathrm{Cr}$ FeFe hydrogenase where a phenylalanine that is close to the active site is replaced with a tyrosine. ${ }^{34}$ At $E=-158 \mathrm{mV}$, $\mathrm{pH} 6.8,30^{\circ} \mathrm{C}$, we measured $\tau=22 \pm 4 \min (n=2)$ with this mutant, similar to the WT $(25 \pm 5 \min n=3$, under the same conditions), suggesting that the absorption of UV that causes the damage is from the $\mathrm{H}$-cluster, not aromatic side-chains.

\section{Solution assays}

Figure 3D shows how exposure of $\mathrm{Cr} F$ eFe hydrogenase to Xe light affects its $\mathrm{H}_{2}$-oxidation activity assayed in solution, with oxidized MV as electron acceptor (see methods). The stock solution of enzyme (approximately $20 \mathrm{nM}$ ) was kept in a quartz cuvette, thermostated at $30{ }^{\circ} \mathrm{C}$, either in the dark or exposed to the full Xe beam (power $=150 \mathrm{~W}$ ), or the same beam but filtered by a UV filter (which absorbs light below $400 \mathrm{~nm}$ ). Exposed to the full $\mathrm{Xe}$ spectrum, the enzyme loses activity with a time constant of about $7 \mathrm{~min}$ (red data in fig. 3D, the red curve shows an ideal first-order decay). Using the UV filter protects the sample (blue data in fig. 3D), confirming the above conclusion that the damage results from UV light. The control sample kept in the dark shows no change in activity over this time period.

\section{TDDFT and DFT modelling.}

To investigate the mechanism of UVB-dependent irreversible degradation of the H-cluster, we examine the first instant of the photodynamics of the active form of the $\mathrm{H}$-cluster by using TDDFT potential energy surface (PES) explorations on a small $\mathrm{Fe}_{2} \mathrm{~S}_{2}$ model of the $\mathrm{H}$-cluster ${ }^{21}$ (see SI section 1). In a second step, we elucidate the fate of the photoproducts at the DFT level using a much larger $\mathrm{Fe}_{2} \mathrm{~S}_{2}$ model in which we include surrounding residues.

For the TDDFT characterization, we assume that the $\mathrm{H}$-cluster is in the $\mathrm{H}_{\mathrm{ox}}$ redox state and therefore the total charge of the $\mathrm{Fe}_{2} \mathrm{~S}_{2}$ model is -2 . Fig. 4 shows the computed spectrum obtained from the first 100 doublet excitations. The requirement for calculating that many 
excited states comes from the complexity of the structure of the dinuclear cluster and our goal to understand the effect of high-energy irradiation. We keep in mind that the TDDFT spectrum of a negatively charged model of a metal-containing active site can give the natures and relative energies of the different excitations, but is not accurate enough to give the absolute excitation energies.

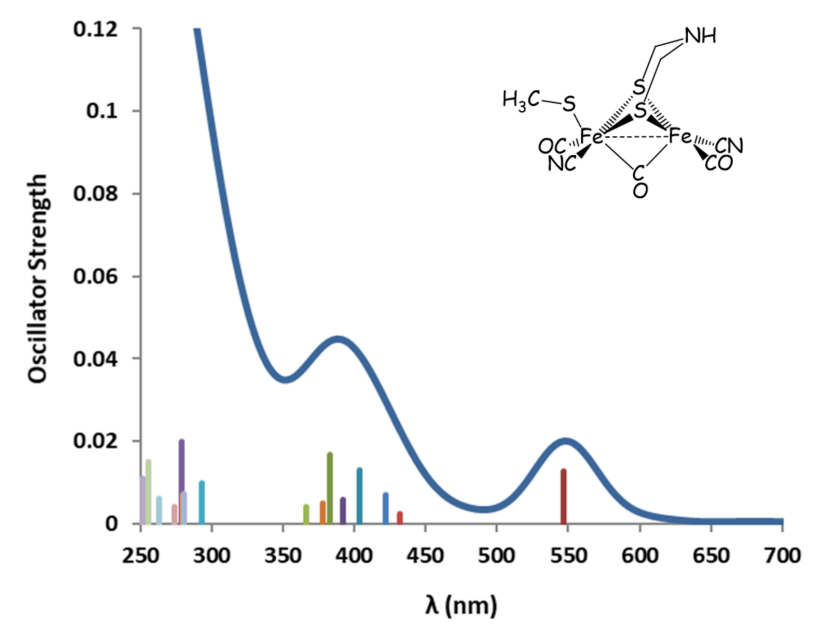

\section{Figure 4.}

The computed electronic spectrum of $\mathrm{Fe}_{2} \mathrm{~S}_{2} \mathrm{H}_{\text {ox }}$. We show as sticks the most intense absorptions, and the resulting spectrum (solid line) calculated as a sum of Gaussian functions centered on the excitation energies and weighted by the computed oscillator strengths.

Three main features are observed in fig. 4. The weak absorption at $550 \mathrm{~nm}$ is due to a single Fe-S charge-transfer (CT) excitation. In the experimental spectrum of the FeFe hydrogenase from C. reinhardtii, ${ }^{15}$ the weak shoulder observed at $420 \mathrm{~nm}$ was assigned to the Fe-S CT band states of the $\mathrm{Fe}_{4} \mathrm{~S}_{4}$ subcluster and it is reasonable to assume that the CT excitations localized on the di-iron subcluster occur in the same energy range. Therefore, we match the computed $550 \mathrm{~nm}$ weak band to the experimental feature at $420 \mathrm{~nm}$. This provides an estimate of the red shift of the TDDFT excitation energies compared to the experimental values.

In fig. 4, we also observe two more intense absorption bands around 380 and $300 \mathrm{~nm}$, which all have a CT character (SI Table 2). Based on the above analysis of the weak feature at $420 \mathrm{~nm}$, we conclude that these bands correspond to absorption in the UV range. From the analysis of the molecular orbital (MO) populations (table S3, Fig. 4), we conclude that occupied frontier MOs are characterized by lower $\mathrm{CO}$ ligand contributions and higher adt sulfur contributions, while the opposite is observed for non-occupied frontier MOs. This implies that all excitations that involve these frontier MOs have a S to CO CT contribution. Moreover, the first four virtual MOs show Fe-C $\pi^{*}$ antibonding orbital combinations, favouring the $\mathrm{Fe}-\mathrm{C}$ bond breaking and therefore $\mathrm{CO}$ dissociation. ${ }^{35,36}$

Regarding the $\mathrm{Fe}_{2} \mathrm{~S}_{2}$ portion of the $\mathrm{H}$-cluster, the possible photochemical processes are $\mathrm{CO}$ release, adt Fe-S bond breaking/weakening, and Fe-S bond breaking/weakening followed by the detachment of the $\mathrm{Fe}_{4} \mathrm{~S}_{4}$ and $\mathrm{Fe}_{2}$ subclusters. To determine which of these reactions occurs, we examined the potential energy surfaces (PES) of the first 20 excited states, calculated by increasing the distal and proximal Fe-C stretching coordinates (fig. 5, panels A 
and $B$, respectively), the distal and proximal Fe-S stretching coordinates (panels $C$ and $D$ ), and the $\mathrm{Fe}-\mathrm{SCH}_{3}$ stretching coordinate (panel E).
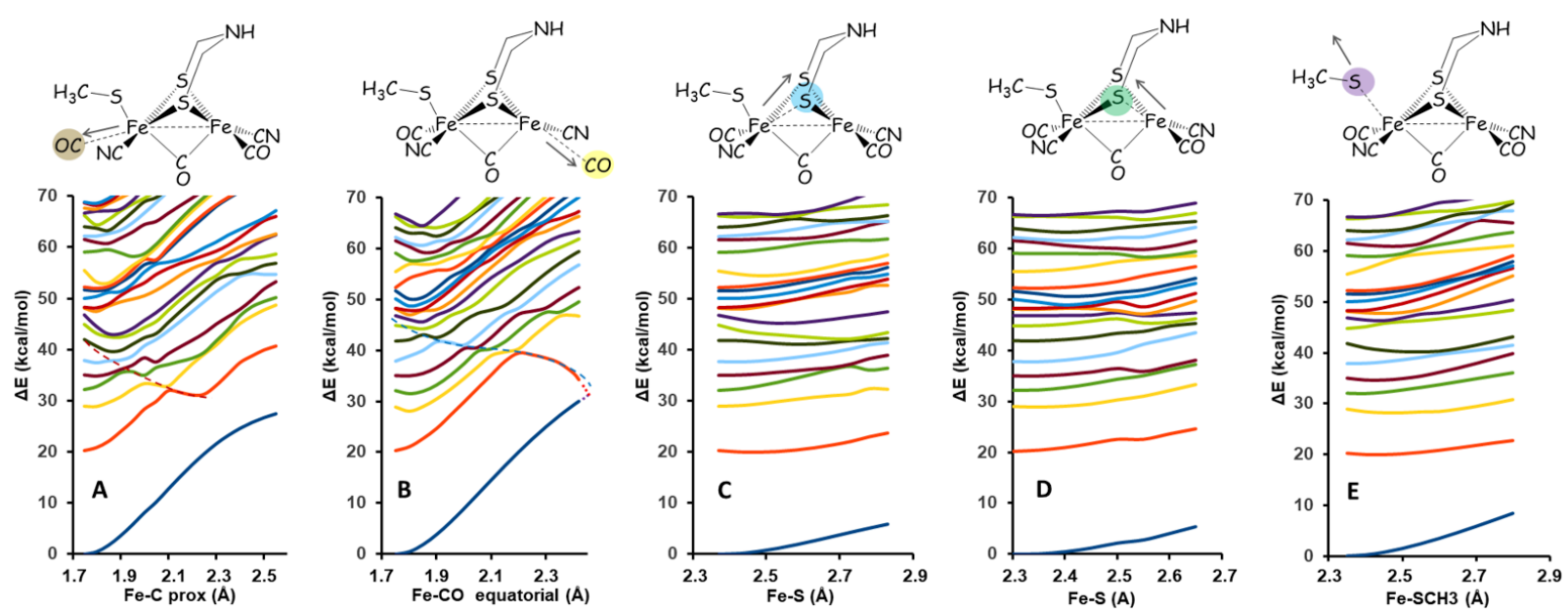

Figure 5. Potential energy surfaces of the ground state and the first 20 excited states of $\mathrm{Fe}_{2} \mathrm{~S}_{2} \mathrm{H}_{\text {ox }}$ model along the stretching coordinates (in $\AA$ ) indicated by arrows: the distance between the proximal $\mathrm{Fe}\left(\mathrm{Fe}_{\mathrm{p}}\right)$ and the proximal $\mathrm{CO}($ panel $A)$, between the distal $\mathrm{Fe}\left(\mathrm{Fe}_{d}\right)$ and the distal $\mathrm{CO}$ (Panel B), between $\mathrm{Fe}_{p}$ and a bridging $S$ (Panel C), between $\mathrm{Fe}_{d}$ and a bridging $S$ (Panel D), and between $\mathrm{Fe}_{p}$ and the $S$ atom that bridges the cubane and the dinuclear cluster (Panel D). Energy differences in $\mathrm{kcal} \cdot \mathrm{mol}^{-1} \mathrm{computed}$ with respect to the minimum ground state energy. Dotted lines (in panels $A$ and $B$ ) show the $C O$ dissociation pathways. In panel $B$ the 1ex/ground state crossing along distal stretching coordinate seems to occur just above $d(F e-C)=2.41 \AA$.

We first focus on the dissociation of the proximal and distal intrinsic $\mathrm{CO}$ ligands. Regarding the ground states, figures $5 \mathrm{~A} \& \mathrm{~B}$ show the energy required to release a CO is lower for $\mathrm{Fe}_{\mathrm{p}}$ than $\mathrm{Fe}_{\mathrm{d}}(22.7 \mathrm{kcal} / \mathrm{mol}$ versus $30.3 \mathrm{kcal} / \mathrm{mol}$, see SI section 1.4 for details $)$. This is easily explained in terms of individual redox states of the two Fe ions. According to DFT calculations, the oxidation states of the iron atoms in $\mathrm{H}_{\mathrm{ox}}$ are $\mathrm{Fe}$ ll for the proximal and Fe' for the distal. (This assignment agrees with some $\mathrm{IR}^{24,25}$, EPR ${ }^{3738}$ and $\mathrm{DFT}^{39,40}$ investigations, but contrasts with the conclusions from other investigations using Hyscore ${ }^{41}$, and $\mathrm{FTIR}^{42}$.) In the ground state, it is more difficult to break a Fel-CO bond than a $\mathrm{Fe}^{\prime \prime}-\mathrm{CO}$ because $\pi$ back-donation of the metal- $\mathrm{CO}$ bond decreases as the redox state of the Fe increases. ${ }^{43}$

Regarding the excited states, Figs $5 \mathrm{~A}$ and $\mathrm{B}$ show that the lower energy surfaces are loosely bound along either $\mathrm{CO}$ dissociation coordinates. Indeed, two series of surface crossings (indicated by dotted lines) indicate putative dissociative pathways for the proximal (panel A) and distal (panel B) CO ligands, starting from 8ex and 9ex, respectively. Higher energy states are very closely spaced, so that the state crossing that one is tempted to observe at high energy cannot not be safely interpreted as a CO dissociation channel. Along the distal dissociation coordinate, 1 ex undergoes state crossing with the ground state at about $\mathrm{d}(\mathrm{Fe}-\mathrm{C})$ $=2.42 \AA$ (panel $B$ ).

Figs $5 \mathrm{C}, \mathrm{D}$ and $\mathrm{E}$ show the PES calculated by increasing the distances of two Fe-S bonds that belong to the $\mathrm{Fe}_{2} \mathrm{~S}_{2}$ core (one distal and one proximal with respect to the $\mathrm{SCH}_{3}{ }^{-}$ligand) and the elongation of the $\mathrm{Fe}-\mathrm{SCH}_{3}{ }^{-}$bond. They do not show any clear dissociative character. In all three cases, the energy of the excited states shows little dependence on bond length. This suggests that either Fe-S bond weakening/breaking is not an active photochemical pathway, or that a transient Fe-S weakening process is followed by fast recombination to the 
initial structure. The latter possibility is supported by the TDDFT geometry optimizations of the 1ex and 2ex states, starting from the structure of the ground state (see Figure S8): in both cases, the calculation evidences a state crossing with the ground state, in which at least one $\mathrm{Fe}-\mathrm{S}$ bond and the $\mathrm{Fe}-\mathrm{SCH}_{3}{ }^{-}$bond are elongated, but these elongations are too small to suggest bond breaking.

We conclude that the most likely photochemical process after irradiation in the UV range of the enzyme is the photolysis of one of the two intrinsic $\mathrm{CO}$ ligands, resulting in the formation of a catalytically inactive 33-electron unsaturated photoproduct $\left(\mathrm{H}_{\mathrm{ox}}{ }^{\text {uns }}\right.$ hereafter).

We now examine the fate of these putative initial photoproducts, aiming at explaining the irreversibility of the photodamage. Irrespective of whether the proximal or distal CO dissociates, the photoproduct is a reactive unsaturated species. From simple electron counting, considering $\mathrm{H}_{\mathrm{ox}}$ as the starting point, the dissociation of the proximal $\mathrm{CO}$ should yield a more stable and less reactive $16 \mathrm{e}+17 \mathrm{e}$ species than the dissociation of the distal $\mathrm{CO}$, which gives a $18 \mathrm{e}+15 \mathrm{e}$ species.

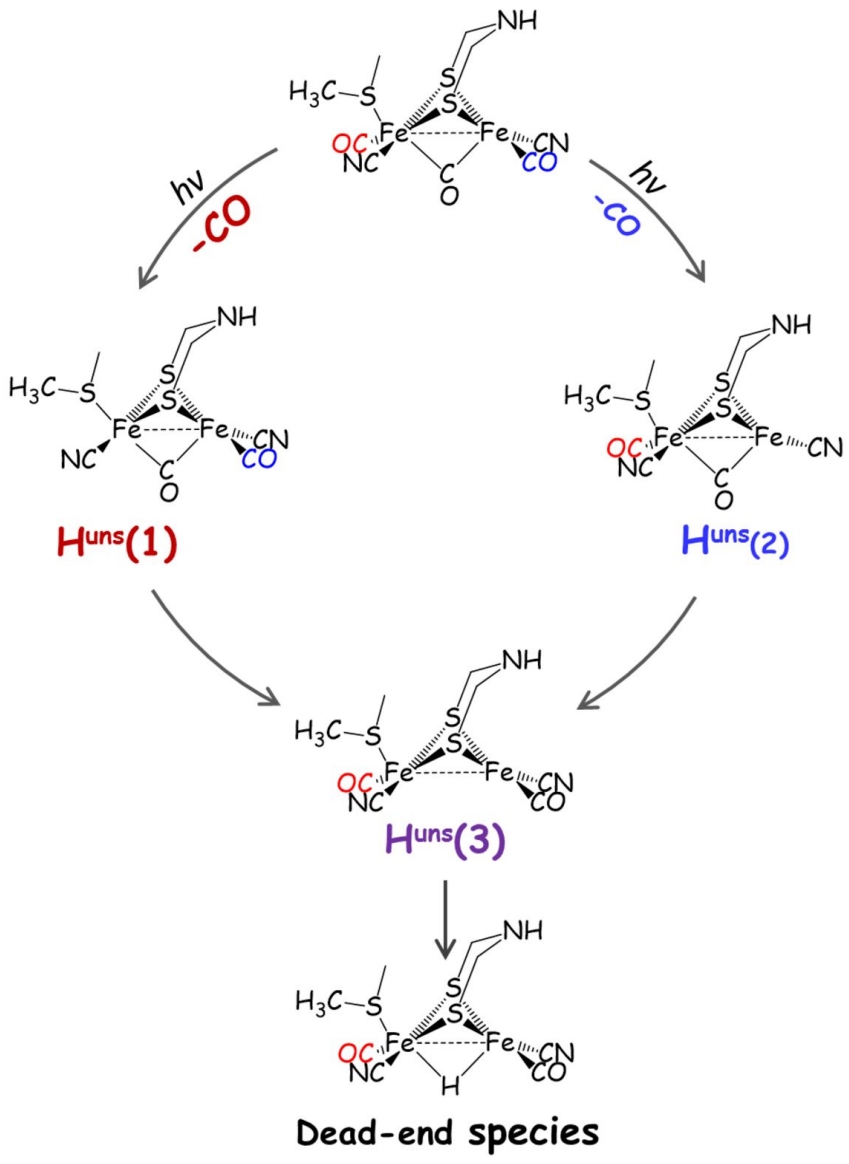

Figure 6. The possible intermediates formed upon photodissociation of an intrinsic CO. Irrespective of the initial $35 e H_{o x}$ or $36 e H_{\text {red }}$ state, the first photoproduct could be $H^{\text {uns }}\left(=H_{o x}\right.$ uns or $H_{\text {red }}$ uns $)$ in which the proximal 1 or the distal $2 \mathrm{CO}$ is photodissociated without further isomerization. Structure $\mathbf{3}$ is the most stable state and derives from the isomerization of $\mathbf{1}$ or $\mathbf{2}$ by moving the bridging CO in equatorial position. The protonation of the reduced form of 3 produces the $\mu \mathrm{H}^{+}$dead-end species. 
Figure 6 depicts some of the species that may be produced upon $\mathrm{CO}$ photodissociation. 1 and 2 are obtained by removing the distal and the proximal $\mathrm{CO}$ ligand respectively without any ligand rearrangement. We also consider the isomerization products 3 and $\mathbf{4}$, where the bridging $\mathrm{CO}$ replaces the photolyzed distal or proximal $\mathrm{CO}$ or occupies the apical position, respectively.

To calculate at the DFT level the structures of these unsaturated forms, we considered a large model in which we embedded the $\mathrm{Fe}_{2} \mathrm{~S}_{2}$ fragment used for TDDFT modelling in a 45 residues double-shell, based on the structure of the enzyme from $D d$ (PDB code $1 \mathrm{HFE}^{6}$ ). SI Table 5 lists the relative energies of the four species shown in fig. 6, and some of their structural and electronic properties. Structure 3 can be easily obtained after photodissociation of either $\mathrm{CO}$ ligand by a simple movement of the bridging $\mathrm{CO}$ toward a terminal position, with a little or no movement of the other ligands. This mechanism is consistent with current knowledge. The DFT calculations of Reiher et $a l^{44}$ and Greco et $a l,{ }^{45,46}$ have shown that a conserved and essential lysine forms a salt bridge with the distal $\mathrm{CN}^{-}$. This strong interaction, stabilized by a further salt bridge between the lysine and a glutamate, should prevent the movement of the equatorial cyanide. Molecular dynamics simulations have shown that the side chain of the conserved phenylalanine that is near the equatorial $\mathrm{CO}$ on $\mathrm{Fe}_{\mathrm{d}}$ is flexible enough to allow the movement of the ligand to the apical position. ${ }^{34}$ Shuffling of the ligands of the H-cluster has been evidenced by FTIR, ${ }^{25,26}$ and a mechanism in which the bridging $\mathrm{CO}$ moves to an apical position was proposed to occur even at cryogenic temperature. ${ }^{24}$

The following two observations are true irrespective of the initial redox state of the $\mathrm{H}$-cluster $\left(\mathrm{H}_{\mathrm{ox}}\right.$ or $\left.\mathrm{H}_{\mathrm{red}}\right)$. First, the structure in which all ligands occupy terminal positions (3) is the most stable of the four species that we considered, and it is characterized by a shorter Fe-Fe bond compared to the saturated form $(-0.102 \AA$ in the reduced form, $-0.048 \AA$ in the oxidized form). This implies an increase of the Fe-Fe bond order which results in the stabilization of the unsaturated form, similarly to what it is observed in $\mathrm{Fe}_{2}(\mathrm{CO})_{8}$ with IR spectroscopy ${ }^{47}$ and $\mathrm{DFT}^{48}$. Second, the loss of a strong field ligand such as $\mathrm{CO}$ upon irradiation implies a decrease of the HOMO/LUMO gap and in particular a decrease of the LUMO energy. This suggests that both $\mathrm{H}_{\text {ox }}{ }^{\text {un }}$ and $\mathrm{H}_{\text {red }}$ uns may be more easily reduced than the corresponding saturated species, and that reduction follows up the formation of initial photoproduct. Reduction of $\mathrm{H}_{\text {red }}$ uns gives the state that we call $\mathrm{H}_{\text {sred }}$ uns.

Finally we investigated the stability of the $H_{\text {red }}$ uns protonated forms. Large model calculations described in SI section 1.6 suggest that irrespective of the starting point $\left(\mathrm{H}_{\text {red }}\right.$ or $\left.\mathrm{H}_{\mathrm{ox}}\right)$ the final unsaturated photoproduct is $\mathrm{H}_{\text {red }}$ uns $(3)$, which is more basic than $\mathrm{H}_{\text {red }}$. Geometry optimization of the two possible protonated species predicts that the $\mu \mathrm{H}^{+}$form is more stable than the apical $\mathrm{H}^{+}$form by $8.7 \mathrm{kcal} / \mathrm{mol}$. We suggest that the $\mu \mathrm{H}^{+}$form is the dead-end, stable, inactive state formed upon UVB irradiation.

\section{Discussion}

There is a very large body of recent work regarding the use of either purified hydrogenases, or photosynthetic organisms that contain hydrogenases or synthetic mimics of the H-cluster for the photoproduction of $\mathrm{H}_{2}{ }^{49-52}$ In all cases, the catalyst is somehow connected to a photosensitizer and exposed to light. Answering the question of which hydrogenase can resist to which wavelengths is therefore crucial. Photodamage of FeFe hydrogenase has been reported in a handful of investigations of the enzyme from $D$. desulfuricans $(D d)$. $^{25,27,28}$ The action spectrum and molecular mechanism of the corresponding reaction has not been described, despite the potential relevance of hydrogenase photoinhibition in the context of 
hydrogen biological photoproduction. The comparison herein between the data now available from $\mathrm{Ca}, \mathrm{Cr}$ and $\mathrm{Dd}$ hydrogenases (this work and refs ${ }^{25,27,28,31}$ ) shows that their photoreactivities vary.

We have previously combined direct photoelectrochemistry and TD-DFT calculations to examine the simplest photochemical reaction of the $\mathrm{H}$-cluster (the photo-induced release of exogenous $\mathrm{CO}$ from the so-called $\mathrm{H}_{\mathrm{ox}}-\mathrm{CO}$ form), and found good semi-quantitative agreement. ${ }^{21,53}$ We stress again that TD-DFT calculations on inorganic clusters can predict the nature of the excitations, their relative energies and the mechanisms of decay, but not the exact values of the excitation energies (the latter are very dependent on the total charge of the model used in the calculation). Here we use this combined approach to investigate the effect of light on the active form of the $\mathrm{H}$-cluster of FeFe hydrogenases; in contrast to our earlier study on the reactivation of $\mathrm{H}_{\mathrm{ox}}-\mathrm{CO}$, our goal here was to search for the mechanism of the reaction and to identify the structure(s) of the photoproduct(s).

We ran experiments where the enzyme is irradiated and its activity is measured either electrochemically (during irradiation, with the enzyme undergoing direct electron transfer to/from a rotating graphite electrode) ${ }^{32}$ or using solution assays (after irradiation, with the artificial redox acceptor methyl viologen). We detected this photodamage with the two hydrogenases that we tested, those from $\mathrm{C}$. reinhardtii $(\mathrm{Cr})$ and $\mathrm{C}$. acetobutylicum $(\mathrm{Ca})$. They house the same, conserved $\mathrm{H}$-cluster, but differ by their size and the number of accessory FeS clusters (four and zero, respectively).

Our experiments show that photoinhibition is irreversible (it is not reversed by going back to dark conditions and we could not reactivate the enzyme by stepping the electrode potential down or by exposing it to exogenous $\mathrm{CO}$ ). We observed in fig. 3 that the activity of the enzyme irradiated by a $150 \mathrm{~W}$ Xe lamp decays with 1 st order kinetics, with a time constant in the range of 10-30 min (the process is slightly faster with the enzyme in solution than when it is wired to an electrode, which somehow "protects" the enzyme against photodamage).

We used filters to examine which range of wavelength is responsible for the photodamage of $\mathrm{Cr}$ and $\mathrm{Ca}$ hydrogenases (figures $3 \mathrm{C}$ and $\mathrm{D}$ ) and we concluded that the effect is induced by UVB irradiation. This is consistent with our earlier report that monochromatic light in the visible range has no effect (neither activation nor inactivation) on the active enzymes. ${ }^{21} \mathrm{We}$ observed that activity of the enzymes changes continuously when the Xe lamp is switched on or off (there is no instant light-induced (in)activation, only a slow decrease). Armstrong and coworkers reported that irradiation with a halogen lamp (which emits no UV) does not inactivate the enzymes from $\mathrm{Ca}$ and $\mathrm{Cr}$, but induces a small, reversible, instant change in catalytic current (SI of ref ${ }^{31}$ ); we saw the same effect, which we tentatively attribute to heating, when we also used a halogen lamp (fig. S12). The data presented herein are therefore consistent with previously published results obtained with the same enzymes.

We considered the possibility that absorption in the UVB range is due to aromatic residues. The acid side chains tyrosine $(\mathrm{Y})$ and tryptophan $(\mathrm{W})$ residues absorb in the range $270-290 \mathrm{~nm}\left(\varepsilon_{280}=1000\right.$ and $5000 \mathrm{M}^{-1} \mathrm{~cm}^{-1}$, respectively). ${ }^{29}$ All $\mathrm{Y}$ and $\mathrm{W}$ residues in FeFe hydrogenases are remote from the $\mathrm{H}$-cluster. There are $9 \mathrm{Y}$ and $4 \mathrm{~W}$ ( 3 of which are surface exposed) in $\mathrm{Cr}$ FeFe hydrogenase, $15 \mathrm{Y}$ and 1 buried $\mathrm{W}$ in Ca FeFe hydrogenase, $15 \mathrm{Y}$ and $6 \mathrm{~W}$ (3 of which are surface exposed) in Dd hydrogenase. It is not practical to replace all of these residues, but we could compare the rates of photo-induced inactivation in the native enzyme and a site-directed mutant where we replaced the phenylalanine that is in Van der Waals contact with the $\mathrm{H}$-cluster with a tyrosine. We observed no effect of the mutation on 
the rate of photoinhibition; this suggests that there is no energy transfer between excited $Y$ and $\mathrm{W}$ and the $\mathrm{H}$-cluster and that the latter is actually the photoreceptor of the photoinhibition. UV irradiation also inactivates other inorganic enzyme active sites. The case of the oxygen evolving cluster (OEC) of Photosystem II is particularly documented, ${ }^{54,55}$ and the idea that it is damaged in vitro by direct absorption of UV has been supported by experiments with other manganese enzymes ${ }^{56}$ and synthetic manganese complexes. ${ }^{57}$ The OEC is also affected by visible or IR irradiation. ${ }^{58}$

We performed TD-DFT calculations to examine which excited states can be produced and how they decay to the ground state. The $\mathrm{Fe}_{4} \mathrm{~S}_{4}$ cubane was not included in the $\mathrm{H}_{\mathrm{ox}}$ model for reasons that we have discussed in our study of $\mathrm{H}_{\mathrm{ox}}-\mathrm{CO}$ photochemistry. ${ }^{21}$ Briefly, considering the $\mathrm{H}$-cluster as a $\mathrm{Fe}_{4} \mathrm{~S}_{4}-\mathrm{Fe}_{2} \mathrm{~S}_{2}$ dyad system, the electronic transitions can be of $\mathrm{Fe}_{2} \mathrm{~S}_{2}$ or $\mathrm{Fe}_{4} \mathrm{~S}_{4}$ localized type or $\mathrm{Fe}_{4} \mathrm{~S}_{4} / \mathrm{Fe}_{2} \mathrm{~S}_{2} \mathrm{CT}$ type, depending on the $\mathrm{MO}$ involved in the monoelectronic transitions. Of these excitations, only the former are relevant to Fe-ligand photochemistry (CO photolysis and Fe-S bond photodissociation). This is because in a $\mathrm{Fe}_{2} \mathrm{~S}_{2}$ localized excitation, an Fe-C/Fe-S antibonding or nonbonding $\mathrm{MO}$ is populated to the detriment of a Fe-C/Fe-S bonding $\mathrm{MO}$, as observed previously in studies of biomimetic models of the $\mathrm{H}$-cluster. ${ }^{35}$

The low energy feature in the calculated spectrum (fig. 4) corresponds to the absorption of the $2 \mathrm{Fe}$ subcluster, which, in experiments, occurs around $420 \mathrm{~nm}$. This band is weak and results from a single $\mathrm{Fe}$ to $\mathrm{S}$ charge transfer. The corresponding low energy excited state cannot decay to a dead-end species, suggesting that this weak absorption band is not responsible for the observed photodamage. This is consistent with our observation that irradiation in the visible range causes no damage. In contrast, the more intense features at higher energy, which probably correspond to absorption in the UV range, correspond to CT from metal ions and the sulfur ligands to $\mathrm{CO}$ ligands (SI table 3 ). Together with the observation that photodamage only occurs at high energy (UVB), this points to the first step of the photoinactivation being the ejection of an intrinsic $\mathrm{CO}$ ligand. Indeed, the potential energy surfaces in fig. 5 rule out photoinduced breaking of the FeS bonds of the H-cluster and evidence the sequence of internal conversions that lead to the dissociation of an intrinsic $\mathrm{CO}$. The picture that emerges of this calculation is therefore that in the first instants of the photodynamics, the absorption of light populates an $\mathrm{H}$-cluster excited state localized on the $\mathrm{Fe}_{2} \mathrm{~S}_{2}$ core, and the subsequent decay of the high energy excited state goes through a proximal or distal Fe-C bond dissociative channel, inducing $\mathrm{CO}$ photolysis and inactivation of the enzyme. This kind of photoreactivity is very common for diiron carbonyl complexes ${ }^{35,59-63}$ but we note that not all Fe-carbonyl bonds in organometallic cofactors are photolabile. For example, the $\left[\mathrm{NiFe}(\mathrm{CN})_{2} \mathrm{CO}\right.$ ] binuclear active of NiFe hydrogenases is not susceptible to photodamage: violet irradiation actually activates the $\mathrm{O}_{2}$-tolerant $\mathrm{NiFe}$ enzyme from $A$. aeolicus, ${ }^{64}$ and unpublished experiments of ours show that the under same conditions as those used in this paper, irradiation by a Xe lamp only activates the standard $\mathrm{NiFe}$ hydrogenase from $D$. fructosovorans (we could not detect any photoinhibition of this NiFe hydrogenase).

In the experiments described herein, the $\mathrm{CO}$ ligand that is released from the H-cluster cannot contribute to inhibition by the so-called cannibalization effect, whereby the CO ligand is grabbed by a nearby, intact $\mathrm{H}$-cluster, to form the inhibited $\mathrm{H}_{\mathrm{ox}}-\mathrm{CO}$ state. Indeed, in PFV experiments, the amount of enzyme adsorbed on the electrode is tiny (in the sub picomolar range), the total amount of $\mathrm{CO}$ molecules released from the $\mathrm{H}$-cluster is even lower, and the free $\mathrm{CO}$ ligands are quickly removed from the rotating electrode surface by convection. In our solution assays, the concentration of enzyme in the stock solution $(20 \mathrm{nM})$ is lower than 
the inhibition constant $(13 \mu \mathrm{M})$ and the stock solution of hydrogenase is diluted before the assay, so no significant cannibalization can occur. ${ }^{12}$ The situation is different when a highly concentrated sample is used in a FTIR or EPR investigation.

The TD-DFT calculations described here cannot define which of the two intrinsic CO ligands actually dissociates from the $\mathrm{H}$-cluster in response to UV irradiation, because the protein environment is not taken into account. On the basis of the structure and the proximity of the substrate channel ${ }^{14}$ from $\mathrm{Fe}_{\mathrm{d}}$, we speculate that the dissociation of the distal $\mathrm{CO}$ dissociation is easier than that of the proximal $\mathrm{CO}$, but this has no consequence on what we believe happens next. The photodissociation of an intrinsic $\mathrm{CO}$ ligands has to be followed by rearrangement. Using DFT computations of a very large model (fig. S2), we concluded that 3 , where all ligands are in terminal positions, is the most stable unsaturated form irrespective of the initial redox state $\left(\mathrm{H}_{\mathrm{ox}}\right.$ or $\left.\mathrm{H}_{\text {red }}\right)$. Also in favor of $\mathbf{3}$ compared to $\mathbf{4}$ is our observation that the F290Y mutation has no effect on the kinetics of inhibition (whereas we have concluded before that it slows the isomerization of the distal $\mathrm{CO}$ from the equatorial to the apical position). ${ }^{34}$ The unsaturated species are more easily reduced than the initial forms, suggesting that the photodamage involves the series of event sketched in scheme 1. Starting from e.g. $\mathrm{H}_{\mathrm{ox}}$, the $\mathrm{H}_{\mathrm{ox}}$ uns photoproduct could undergo reduction directly to the most stable $\mathrm{H}_{\text {red }}$ uns. the same species can be produced directly from $\mathrm{H}_{\text {red }}$. Further reduction may give a hyper reduced $\mathrm{H}_{\text {sred }}$ uns form with about the same reactivity.

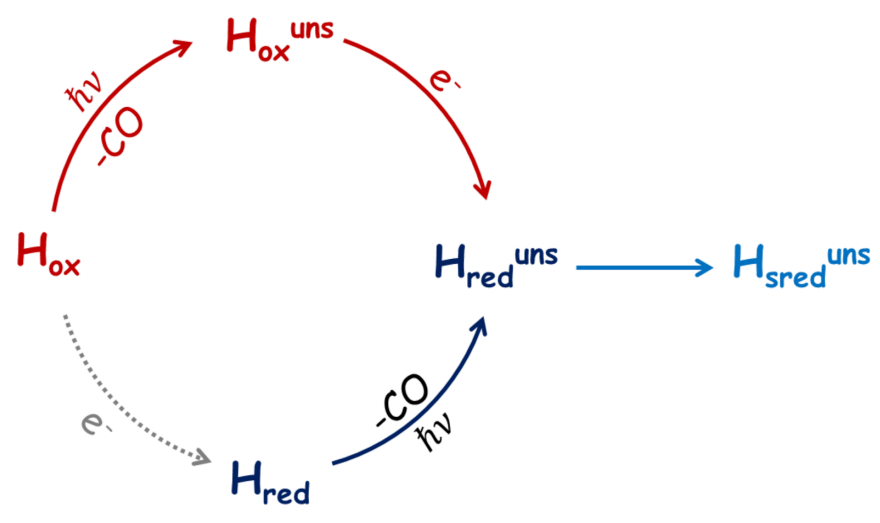

Scheme 1. The series of steps occurring during the photodamage of $H_{o x}$ or $H_{\text {red. }}$ In both cases the $H$-cluster reaches an unsaturated reduced state $\left(H_{\text {red }}{ }^{\text {uns }}\right)$ which could be further reduced to a super reduced state $\left(H_{\text {sred }}\right.$ uns $)$.

Both $\mathrm{H}_{\text {red }}$ uns and $\mathrm{H}_{\text {sred }}$ uns have two open coordination sites, one bridging the Fe ions and the other apical on $\mathrm{Fe}_{\mathrm{d}}$, and they may react with nearby ligands, such as the photolyzed intrinsic carbonyl, $\mathrm{H}_{2} \mathrm{O}, \mathrm{H}_{2}$ or $\mathrm{H}^{+}$. The recombination with $\mathrm{CO}$ would restore the initial $\mathrm{H}_{\text {red }} / \mathrm{H}_{\mathrm{ox}}$ form, so this recombination process, which probably occurs, merely decreases the apparent rate of inactivation. Binding of a water molecule would be possible, but in all available crystal structures, the environment of the $\mathrm{H}$-cluster is rather dry. We also consider the binding of dihydrogen as unlikely, first because we have observed no effect of hydrogen pressure on the kinetics of inactivation, second because we expect that binding of $\mathrm{H}_{2}$ to a reduced or hyper-reduced unsaturated system should be endergonic. Last, we note that both $\mathrm{H}_{\text {red }}{ }^{\text {uns }}$ or $\mathrm{H}_{\text {sred }}$ uns should be much more basic that $\mathrm{H}_{\text {red }}$. A first protonation will surely occur at the bridging position, as indicated by the geometry optimization of the $\mathrm{H}_{\text {red }}$ uns protonated forms (the $\mu \mathrm{H}^{+}$is lower in energy than apical terminal $\mathrm{H}^{+}$by $8.7 \mathrm{kcal} / \mathrm{mol}$ ). This $\mu \mathrm{H}^{+}$form is very stable ${ }^{65}$ and its further protonation should not lead to the formation of the $\sigma-\mathrm{H}_{2}$ complex and 
the release of molecular hydrogen. We propose that it is the final, dead-end product of the photoinactivation reaction. Let us note that Haumann et al. have recently proposed that a hydride bridges the two Fe ions of the saturated dinuclear subcluster in reduced, inactive forms of the $\mathrm{H}$-cluster. ${ }^{66}$

Our conclusion that UVB is responsible for the photoinhibition of $\mathrm{Ca}$ and $\mathrm{Cr}$ hydrogenases contrasts with the earlier observation that the enzyme from $D d$ is destroyed upon illumination in the visible range. ${ }^{25,27,28}$ Indeed, in ref ${ }^{25}$, Albracht and coworkers emphasized that they used a halogen or a Xe arc lamp, and a glass light guide that "eliminated most of the UV contribution from the light used," and in ref ${ }^{28}$, Ruediger et al observed the effects of light with a halogen lamp and a glass electrochemical cell. At this point, we can only speculate that the photoinhibition mechanism that we described is also operational in Dd hydrogenase, but for a reason that is unclear, absorption in the visible range, rather than UV, triggers the reaction. We can hypothesize that the protein environment shifts the CT excitations that are active in photodamage to the high energy range of the halogen lamp spectrum. Whether UV or visible light is responsible for photodamage does not depend on just the number of accessory FeS clusters (two in $\mathrm{Dd}$ hydrogenase, compared to zero and four in $\mathrm{Ca}$ and $\mathrm{Cr}$ hydrogenases). We note that the enzyme from $D d$ is only sensitive to photoinhibition under oxidizing conditions (according to the results in fig 2 of ref ${ }^{28}$ ), unlike the enzymes from $\mathrm{Ca}$ and $\mathrm{Cr}$ (fig 3 B \& C herein). For unknown reasons, the enzyme from $D d$ appears to have a number of peculiar properties (the formation of the so-called $\mathrm{H}_{\text {ox }}$-inact state, for example, has only been observed with $D d$ and Clostridium beijerinckii FeFe hydrogenases ${ }^{67}$ ), and it is also particularly sensitive to aerobic ${ }^{14}$ and anaerobic ${ }^{34}$ oxidative inactivation. ${ }^{31,68}$

We end this paper by commenting on the consequences of hydrogenase photoinhibition in the context of $\mathrm{H}_{2}$ photoproduction. There are attempts to "domesticate" photosynthetic microorganisms such as green algae to make them produce dihydrogen using the energy from sunlight. ${ }^{69-72}$ Algae are notoriously sensitive to UV, ${ }^{73,74}$ but we are not aware of any previous investigation of the photodamage of hydrogenase in vivo. Regarding the development of " $\mathrm{H}_{2}$ farms," hydrogenase photoinhibition should not be an issue since the bioreactor used for biological $\mathrm{H}_{2}$ photoproduction should screen the UV. Photoinhibition may be more of an issue in artificial photocatalytic dyads where either an enzyme or a bacterium receives electrons from a sunlight-harvesting organic dye, a photosynthetic enzyme or a semiconductor. ${ }^{49,52,75-79}$ Happe and coworkers have indeed observed that UV light contributes to light-dependent ET between 5-carboxyeosin $\left(\lambda_{\max }=516 \mathrm{~nm}\right)$ and $\mathrm{Cr} F \mathrm{FeF}$ hydrogenase ${ }^{72}$ and in the light of our results, exposure to UV may actually negatively contribute to the efficiency of this device.

\section{Methods}

\section{Experiments.}

The enzyme from $\mathrm{Cr}$ was expressed in Shewanella oneidensis. The enzyme from Ca was produced homologously. The samples were prepared as described previously. ${ }^{80,81}$

The light sources used in this work were a Newport $150 \mathrm{~W}$ Xenon arc lamp (Oriel Apex Monochromator illuminator 70612), directed to the sample by a Newport Oriel 77578 optical fiber $(1 \mathrm{~cm}$ diameter, transmittance range $280-2200 \mathrm{~nm}$ according to the manufacturer's specifications), or a Fiberoptic-Heim LQ 1600 Halogen lamp. The diameter of the beam was around $1.5 \mathrm{~cm}$ at the level of the electrode. Our setup does not allow the power of the Xe light source to be varied. We used two longpass filters, whose absorption spectra are shown 
in figure S11: a borosilicate filter which blocks UVB, and a UV filter which blocks UV-A and UV-B.

In electrochemical experiments, we irradiated the enzyme adsorbed on the surface of a graphite working RDE (typical electrode rotation rate $3 \mathrm{krpm}$ ), through quartz window at the bottom of the glass electrochemical cell (see the photograph in fig. S15); this prevented light diffraction and UV absorption. The electrochemical experiments were performed in a $0.1 \mathrm{M}$ potassium phosphate buffer $\mathrm{pH}$ 6.8. Regarding the experiments shown in figs $3 \mathrm{~A}, \mathrm{~B} \& \mathrm{C}$, the time constant of inactivation ( $\tau$, in the equation $\mathrm{i}=\mathrm{cst} \times \exp (-\mathrm{t} / \tau)$ ) (where "cst" is a constant) was deduced by fitting $y=\operatorname{cst} \times(1-t / \tau)$ to the linear current trace, using the free software QSoas. ${ }^{82}$

Solution assays (fig. 3D) were performed at $30{ }^{\circ} \mathrm{C}, \mathrm{pH}=7,1 \mathrm{~atm} \mathrm{H}_{2}$, in a mixed buffer consisting of MES, CHES, HEPES, TAPS, acetate, EDTA ( $5 \mathrm{mM}$ each), $0.1 \mathrm{M} \mathrm{NaCl}$, under 1 bar $\mathrm{H}_{2}$, and with $20 \mathrm{mM}$ oxidized methyl viologen (MV) as electron acceptor. The enzyme sample was illuminated for 5 or $15 \mathrm{~min}$ with the Xenon lamp in a quartz cell $(1 \mathrm{~mm}$ light path, Precision Cells). In a glass cell containing $1.8 \mathrm{ml}$ of mixed buffer saturated with $\mathrm{H}_{2}$, we put $200 \mu \mathrm{l}$ of MV (0.2 M stock solution) and we recorded the absorbance at $604 \mathrm{~nm}$ to obtain the baseline. The reaction was started by adding $5 \mu \mathrm{l}$ of enzyme solution (previously exposed to white light or kept in the dark) and the increase in absorbance induced by the reduction of MV was measured at $604 \mathrm{~nm}$. The concentration of the enzyme stock solution was unknown, which prevented us from determining absolute turnover rates.

\section{Computations.}

The level of theory adopted is different for TDDFT and DFT computations. For the former it is crucial to better describe the charge-transfer character of the excitations and for this reason a hybrid functional is needed. For the latter, however, due to the size of the model considered, it is important to use Resolution-of-identity (RI) technique to speed up computations and in this case only a pure functional can be used.

The TDDFT computation were performed using the hybrid Generalized Gradient Approximation (GGA) PBE0 ${ }^{83}$ DFT functional as implemented in the TURBOMOLE suite of programs ${ }^{84}$. Basis sets of triple- $\zeta$ plus polarization split valence quality ${ }^{85}$ were adopted for all atoms. The choice of this functional has been made on the basis of the $\mathrm{H}_{\mathrm{ox}} \mathrm{Fe}_{2} \mathrm{~S}_{2}$ optimized geometry compared to the XRD structure. Indeed PBEO gives the best agreement among the hybrid functional considered (further information on the calculations is available in the $\mathrm{SI}$ section 1). In section 1.3 are also reported the effect of the DFT functionals and of the total charge of the model on the computed spectra. Excited PESs have been scanned along selected Fe-Ligand (Fe-L) bond stretching coordinates as follows. For each step, the ground state structure was first optimized by keeping the elongated Fe- $L$ distance fixed. The sampling of the excited PES has been carried out with a step of $0.05 \AA$. For each distance the vertical excitation energies have been computed and the resulting profile for each excited state approximates the effect of stretching the bond on the excited surface. ${ }^{86}$

The DFT computation on the large $\mathrm{Fe}_{2} \mathrm{~S}_{2}$ model were performed using the pure GGA BP86 $6^{87,88}$ DFT functional and RI technique ${ }^{89}$ as implemented in TURBOMOLE. Basis sets of double- $\zeta$ plus polarization split valence quality ${ }^{85}$ were adopted for all atoms. 


\section{Associated content}

\section{Author Information}

Corresponding authors

* christophe.leger@imm.cnrs.fr

* luca.bertini@unimib.it

\section{Author contributions}

The manuscript was written through contributions of all authors.

\section{Supporting Information}

The Supporting Information is available free of charge on the ACS Publications website. Models and computational details of DFT and TDDFT calculations. Absorption spectra of the filters. Photography of the electrochemical cell. Experimental data with Halogen Lamp and UV photoinhibition by Xenon lamp on FeFe hydrogenases from $\mathrm{Cr}\left(100 \%\right.$ and $\left.10 \% \mathrm{H}_{2}\right)$ and Ca.

\section{Acknowledgements}

The French teams were supported by CNRS, Aix Marseille Université, INSA, CEA, Agence Nationale de la Recherche (ANR-12-BS08-0014, ANR-14-CE05-0010) and the Excellence Initiative of Aix-Marseille University - A*MIDEX, a French "Investissements d'Avenir" programme (ANR-11-IDEX-0001-02). The French authors are part of the French bioinorganic chemistry network (www.frenchbic.cnrs.fr). 


\section{References}

(1) Nicolet, Y.; de Lacey, A. L.; Vernède, X.; Fernandez, V. M.; Hatchikian, E. C.; Fontecilla-Camps, J. C. J. Am. Chem. Soc. 2001, 123, 1596-1601.

(2) Silakov, A.; Wenk, B.; Reijerse, E.; Lubitz, W. Phys. Chem. Chem. Phys. 2009, 11, 6592-6599.

(3) Berggren, G.; Adamska, A.; Lambertz, C.; Simmons, T. R.; Esselborn, J.; Atta, M.; Gambarelli, S.; Mouesca, J. M.; Reijerse, E.; Lubitz, W.; Happe, T.; Artero, V.; Fontecave, M. Nature 2013, 499, 66-69.

(4) Fontecilla-Camps, J. C.; Volbeda, A.; Cavazza, C.; Nicolet, Y. Chem. Rev. 2007, 107, 4273-4303.

(5) Mulder, D. W.; Boyd, E. S.; Sarma, R.; Lange, R. K.; Endrizzi, J. A.; Broderick, J. B.; Peters, J. W. Nature 2010, 465, 248-251.

(6) Nicolet, Y.; Piras, C.; Legrand, P.; Hatchikian, C. E.; Fontecilla-Camps, J. C. Structure 1999, 7, $13-23$.

(7) Caserta, G.; Adamska-Venkatesh, A.; Pecqueur, L.; Atta, M.; Artero, V.; Roy, S.; Reijerse, E.; Lubitz, W.; Fontecave, M. Biochim. Biophys. Acta 2016, 1857, 1734-1740.

(8) Peters, J. W.; Lanzilotta, W. N.; Lemon, B. J.; Seefeldt, L. C. Science 1998, 282, 1853-1858.

(9) Poudel, S.; Tokmina-Lukaszewska, M.; Colman, D. R.; Refai, M.; Schut, G. J.; King, P. W.; Maness, P.C.; Adams, M. W. W.; Peters, J. W.; Bothner, B.; Boyd, E. S. Biochim. Biophys. Acta 2016, 1860, 1910-1921.

(10) Lubitz, W.; Ogata, H.; Rüdiger, O.; Reijerse, E. Chem. Rev. 2014, 114, 4081-4148.

(11) Bennett, B.; Lemon, B. J.; Peters, J. W. Biochemistry 2000, 39, 7455-7460.

(12) Baffert, C.; Bertini, L.; Lautier, T.; Greco, C.; Sybirna, K.; Ezanno, P.; Etienne, E.; Soucaille, P.; Bertrand, P.; Bottin, H.; Meynial-Salles, I.; De Gioia, L.; Léger, C. J. Am. Chem. Soc. 2011, 133, 2096-2099.

(13) Orain, C.; Saujet, L.; Gauquelin, C.; Soucaille, P.; Meynial-Salles, I.; Baffert, C.; Fourmond, V.; Bottin, H.; Léger, C. J. Am. Chem. Soc. 2015, 137, 12580-12587.

(14) Kubas, A.; Orain, C.; De Sancho, D.; Saujet, L.; Sensi, M.; Gauquelin, C.; Meynial-Salles, I.; Soucaille, P.; Bottin, H.; Baffert, C.; Fourmond, V.; Best, R. B.; Blumberger, J.; Léger, C. Nat. Chem. 2017, 9, 88-95.

(15) Swanson, K. D.; Ratzloff, M. W.; Mulder, D. W.; Artz, J. H.; Ghose, S.; Hoffman, A.; White, S.; Zadvornyy, O. A.; Broderick, J. B.; Bothner, B.; King, P. W.; Peters, J. W. J. Am. Chem. Soc. 2015, 137, 1809-1816.

(16) Kowal, A. T.; Adams, M. W.; Johnson, M. K. J. Biol. Chem. 1989, 264, 4342-4348.

(17) Silakov, A.; Kamp, C.; Reijerse, E.; Happe, T.; Lubitz, W. Biochemistry 2009, 48, 7780-7786.

(18) Hajj, V.; Baffert, C.; Sybirna, K.; Meynial-Salles, I.; Soucaille, P.; Bottin, H.; Fourmond, V.; Léger, C. Energy Environ. Sci. 2014, 7, 715-719.

(19) Megarity, C. F.; Esselborn, J.; Hexter, S. V.; Wittkamp, F.; Apfel, U. P.; Happe, T.; Armstrong, F. A. J. Am. Chem. Soc. 2016, 138, 15227-15233.

(20) Thauer, R. K.; Käufer, B.; Zähringer, M.; Jungermann, K. Eur. J. Biochem. 1974, 42, 447-452.

(21) Sensi, M.; Baffert, C.; Greco, C.; Caserta, G.; Gauquelin, C.; Saujet, L.; Fontecave, M.; Roy, S.; Artero, V.; Soucaille, P.; Meynial-Salles, I.; Bottin, H.; de Gioia, L.; Fourmond, V.; Léger, C.; Bertini, L. J. Am. Chem. Soc. 2016, 138, 13162-13618.

(22) Mirmohades, M.; Adamska-Venkatesh, A.; Sommer, C.; Reijerse, E.; Lomoth, R.; Lubitz, W.; Hammarström, L. J. Phys. Chem. Lett. 2016, 7, 3290-3293.

(23) Lemon, B. J.; Peters, J. W. J. Am. Chem. Soc. 2000, 122, 3793-3794.

(24) Chen, Z.; Lemon, B. J.; Huang, S.; Swartz, D. J.; Peters, J. W.; Bagley, K. A. Biochemistry 2002, 41, 2036-2043.

(25) Roseboom, W.; De Lacey, A. L.; Fernandez, V. M.; Hatchikian, E. C.; Albracht, S. P. J. J. Biol. Inorg. Chem. 2006, 11, 102-118.

(26) Senger, M.; Mebs, S.; Duan, J.; Wittkamp, F.; Apfel, U. P.; Heberle, J.; Haumann, M.; Stripp, S. T. Proc. Natl. Acad. Sci. U. S. A. 2016, 113, 8454-8459.

(27) Albracht, S. P. J.; Roseboom, W.; Hatchikian, E. C. J. Biol. Inorg. Chem. 2006, 11, 88-101.

(28) Rodríguez-Maciá, P.; Birrell, J. A.; Lubitz, W.; Rüdiger, O. ChemPlusChem 2016, 82, 540-545.

(29) Wetlaufer, D. B. Adv. Protein Chem. 1962, 17, 333-390.

(30) Sensi, M.; del Barrio, M.; Baffert, C.; Fourmond, V.; Léger, C. Current Opinion in Electrochemistry 2017, doi: 10.1016/j.coelec.2017.08.005.

(31) Goldet, G.; Brandmayr, C.; Stripp, S. T.; Happe, T.; Cavazza, C.; Fontecilla-Camps, J. C.; Armstrong, F. A. J. Am. Chem. Soc. 2009, 131, 14979-14989.

(32) Fourmond, V.; Léger, C. Current Opinion in Electrochemistry 2017, 1, 110-120.

(33) Fourmond, V.; Baffert, C.; Sybirna, K.; Dementin, S.; Abou-Hamdan, A.; Meynial-Salles, I.; Soucaille, P.; Bottin, H.; Léger, C. Chem. Commun. 2013, 49, 6840-6842.

(34) Fourmond, V.; Greco, C.; Sybirna, K.; Baffert, C.; Wang, P. H.; Ezanno, P.; Montefiori, M.; Bruschi, M.; Meynial-Salles, I.; Soucaille, P.; Blumberger, J.; Bottin, H.; De Gioia, L.; Léger, C. Nat. Chem. 2014, 6, 336-342.

(35) Bertini, L.; Greco, C.; Fantucci, P.; De Gioia, L. Int. J. Quantum Chem. 2014, 114, 851-861.

(36) Bertini, L.; Fantucci, P.; De Gioia, L.; Zampella, G. Inorg. Chem. 2013, 52, 9826-9841.

(37) Mulder, D. W.; Ratzloff, M. W.; Shepard, E. M.; Byer, A. S.; Noone, S. M.; Peters, J. W.; Broderick, J. B.; King, P. W. J. Am. Chem. Soc. 2013, 135, 6921-6929.

(38) Myers, W. K.; Stich, T. A.; Suess, D. L. M.; Kuchenreuther, J. M.; Swartz, J. R.; Britt, R. D. J. Am. Chem. 
Soc. 2014, 136, 12237-12240.

(39) Fiedler, A. T.; Brunold, T. C. Inorg. Chem. 2005, 44, 9322-9334.

(40) Bruschi, M.; Greco, C.; Fantucci, P.; De Gioia, L. Inorg. Chem. 2008, 47, 6056-6071.

(41) Silakov, A.; Reijerse, E. J.; Albracht, S. P. J.; Hatchikian, E. C.; Lubitz, W. J. Am. Chem. Soc. 2007, 129, 11447-11458.

(42) Adamska, A.; Silakov, A.; Lambertz, C.; Rüdiger, O.; Happe, T.; Reijerse, E.; Lubitz, W. Angew. Chem. Int. Ed Engl. 2012, 51, 11458-11462.

(43) Willner, H.; Aubke, F. Organometallics 2003, 22, 3612-3633.

(44) Finkelmann, A. R.; Stiebritz, M. T.; Reiher, M. Chem. Sci. 2014, 5, 215-221.

(45) Greco, C.; Bruschi, M.; Heimdal, J.; Fantucci, P.; De Gioia, L.; Ryde, U. Inorg. Chem. 2007, 46, 7256-7258.

(46) Greco, C.; Bruschi, M.; Fantucci, P.; Ryde, U.; De Gioia, L. Chemistry 2011, 17, 1954-1965.

(47) Fletcher, S. C.; Poliakoff, M.; Turner, J. J. Inorg. Chem. 1986, 25, 3597-3604.

(48) Bertini, L.; Bruschi, M.; De Gioia, L.; Fantucci, P. J. Phys. Chem. A 2007, 111, 12152-12162.

(49) Mersch, D.; Lee, C. Y.; Zhang, J. Z.; Brinkert, K.; Fontecilla-Camps, J. C.; Rutherford, A. W.; Reisner, E. J. Am. Chem. Soc. 2015, 137, 8541-8549.

(50) Brown, K. A.; Wilker, M. B.; Boehm, M.; Dukovic, G.; King, P. W. J. Am. Chem. Soc. 2012, 134, 5627-5636.

(51) Reisner, E.; Powell, D. J.; Cavazza, C.; Fontecilla-Camps, J. C.; Armstrong, F. A. J. Am. Chem. Soc. 2009, 131, 18457-18466.

(52) Lubner, C. E.; Applegate, A. M.; Knörzer, P.; Ganago, A.; Bryant, D. A.; Happe, T.; Golbeck, J. H. Proc. Natl. Acad. Sci. U. S. A. 2011, 108, 20988-20991.

(53) Greco, C.; Fourmond, V.; Baffert, C.; Wang, P. H.; Dementin, S.; Bertrand, P.; Bruschi, M.; Blumberger, J.; de Gioia, L.; Léger, C. Energy Environ. Sci. 2014, 7, 3543-3573.

(54) Keren, N.; Krieger-Liszkay, A. Physiol. Plant. 2011, 142, 1-5.

(55) Vass, I. Biochim. Biophys. Acta 2012, 1817, 209-217.

(56) Hakala, M.; Rantamäki, S.; Puputti, E. M.; Tyystjärvi, T.; Tyystjärvi, E. J. Exp. Bot. 2006, 57, 1809-1816.

(57) Antal, T. K.; Lo, W.; Armstrong, W. H.; Tyystjarv, Ei. Photochem. Photobiol. 2009, 663-668.

(58) Boussac, A.; Sugiura, M.; Lai, T.L.; Rutherford, A. W. Philos. Trans. R. Soc. Lond. B Biol. Sci. 2008, 363, 1203-1210.

(59) Johnson, M.; Thuman, J.; Letterman, R. G.; Stromberg, C. J.; Webster, C. E.; Heilweil, E. J. J. Phys. Chem. B 2013, 117, 15792-15803.

(60) Ridley, A. R.; Stewart, A. I.; Adamczyk, K.; Ghosh, H. N.; Kerkeni, B.; Guo, Z. X.; Nibbering, E. T. J.; Pickett, C. J.; Hunt, N. T. Inorg. Chem. 2008, 47, 7453-7455.

(61) Bingaman, J. L.; Kohnhorst, C. L.; Van Meter, G. A.; McElroy, B. A.; Rakowski, E. A.; Caplins, B. W.; Gutowski, T. A.; Stromberg, C. J.; Webster, C. E.; Heilweil, E. J. J. Phys. Chem. A 2012, 116, 7261-7271.

(62) Kania, R.; Frederix, P. W. J. M.; Wright, J. A.; Ulijn, R. V.; Pickett, C. J.; Hunt, N. T. J. Chem. Phys. 2012, 136, 044521.

(63) Goy, R.; Bertini, L.; Rudolph, T.; Lin, S.; Schulz, M.; Zampella, G.; Dietzek, B.; Schacher, F. H.; De Gioia, L.; Sakai, K.; Weigand, W. Chem. - Eur. J.I 2016, 23, 334-345.

(64) Ciaccafava, A.; Hamon, C.; Infossi, P.; Marchi, V.; Giudici-Orticoni, M.T.; Lojou, E. Phys. Chem. Chem. Phys. 2013, 15, 16463.

(65) Barton, B. E.; Zampella, G.; Justice, A. K.; De Gioia, L.; Rauchfuss, T. B.; Wilson, S. R. Dalton Trans. 2010, 39, 3011-3019.

(66) Mebs, S.; Senger, M.; Duan, J.; Wittkamp, F.; Apfel, U. P.; Happe, T.; Winkler, M.; Stripp, S. T.; Haumann, M. J. Am. Chem. Soc. 2017, doi 10.1021/jacs.7b07548.

(67) Morra, S.; Arizzi, M.; Valetti, F.; Gilardi, G. Biochemistry 2016, 55, 5897-5900.

(68) Liebgott, P.P.; Leroux, F.; Burlat, B.; Dementin, S.; Baffert, C.; Lautier, T.; Fourmond, V.; Ceccaldi, P.; Cavazza, C.; Meynial-Salles, I.; Soucaille, P.; Fontecilla-Camps, J. C.; Guigliarelli, B.; Bertrand, P.; Rousset, M.; Léger, C. Nat. Chem. Biol. 2010, 6, 63-70.

(69) Hemschemeier, A.; Melis, A.; Happe, T. Photosynth. Res. 2009, 102, 523-540.

(70) Ghirardi, M. L. Photosynth. Res. 2015, 125, 383-393.

(71) Noone, S.; Ratcliff, K.; Davis, R.; Subramanian, V.; Meuser, J.; Posewitz, M. C.; King, P. W.; Ghirardi, M. L. Algal Research 2017, 22, 116-121.

(72) Adam, D.; Bösche, L.; Castañeda-Losada, L.; Winkler, M.; Apfel, U. P.; Happe, T. ChemSusChem 2017, 10, 894-902.

(73) Holzinger, A.; Lütz, C. Micron 2006, 37, 190-207.

(74) Pescheck, F.; Lohbeck, K. T.; Roleda, M. Y.; Bilger, W. J. Photochem. Photobiol. B 2014, 132, 85-93.

(75) Ladomenou, K.; Natali, M.; lengo, E.; Charalampidis, G.; Scandola, F.; Coutsolelos, A. G. Coord. Chem. Rev. 2015, 304-305, 38-54.

(76) Wang, F.; Wang, W. G.; Wang, H. Y.; Si, G.; Tung, C. H.; Wu, L. Z. ACS Catal. 2012, 2, 407-416.

(77) Honda, Y.; Hagiwara, H.; Ida, S.; Ishihara, T. Angew. Chem. Int. Ed Engl. 2016, 55, 8045-8048.

(78) Hambourger, M.; Gervaldo, M.; Svedruzic, D.; King, P. W.; Gust, D.; Ghirardi, M.; Moore, A. L.; Moore, T. A. J. Am. Chem. Soc. 2008, 130, 2015-2022.

(79) Lomoth, R.; Ott, S. Dalton Trans. 2009, 0, 9952-9959.

(80) Gauquelin, C.; Baffert, C.; Richaud, P.; Kamionka, E.; Etienne, E.; Guieysse, D.; Girbal, L.; Fourmond, 
V.; André, I.; Guigliarelli, B.; Léger, C.; Soucaille, P.; Meynial-Salles, I. Biochim. Biophys. Acta 2017, doi: 10.1016/j.bbabio.2017.08.010 .

(81) Sybirna, K.; Antoine, T.; Lindberg, P.; Fourmond, V.; Rousset, M.; Méjean, V.; Bottin, H. BMC Biotechnol. 2008, 8, 73.

(82) Fourmond, V. Anal. Chem. 2016, 88, 5050-5052.

(83) Adamo, C.; Scuseria, G. E.; Barone, V. J. Chem. Phys. 1999, 111, 2889-2899.

(84) Ahlrichs, R.; Bär, M.; Häser, M.; Horn, H.; Kölmel, C. Chem. Phys. Lett. 1989, 162, 165-169.

(85) Schäfer, A.; Huber, C.; Ahlrichs, R. J. Chem. Phys. 1994, 100, 5829-5835.

(86) Dunietz, B. D.; Dreuw, A.; Head-Gordon, M. J. Phys. Chem. B 2003, 107, 5623-5629.

(87) Becke, A. D. Phys. Rev. A Gen. Phys. 1988, 38, 3098-3100.

(88) Perdew, J. P. Phys. Rev. B Condens. Matter 1986, 33, 8822-8824.

(89) Eichkorn, K.; Weigend, F.; Treutler, O.; Ahlrichs, R. Theor. Chem. Acc. 1997, 97, 119-124. 
TOC IMAGE

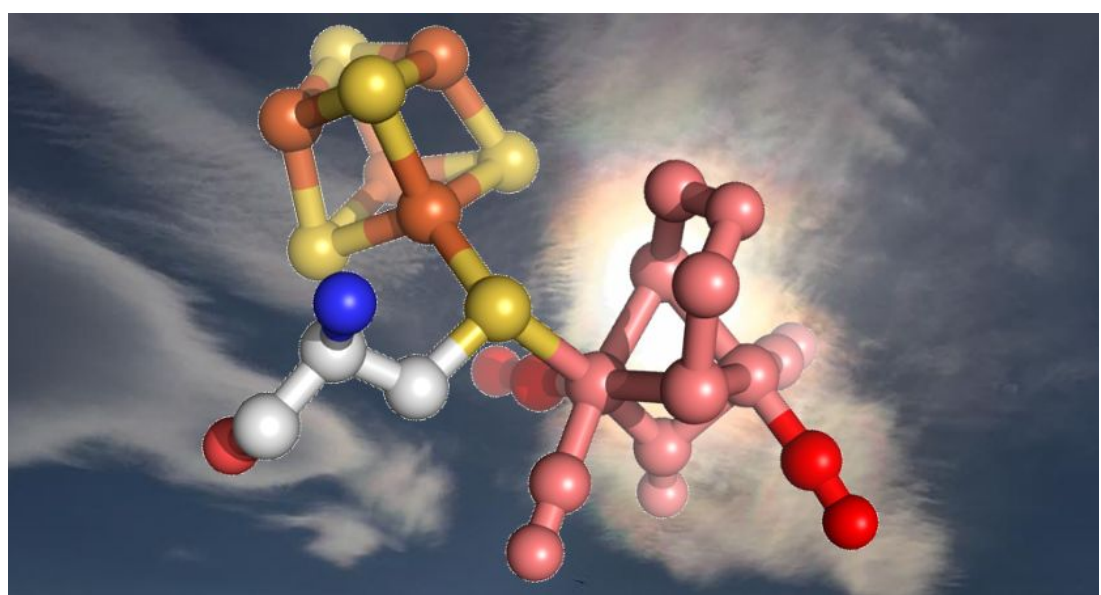

